\title{
HOMEM E RELIGIÃO NO MOVIMENTO NEOHEGELIANO DE ESQUERDA: UMA LEITURA DE BRUNO BAUER, MAX STIRNER E LUDWIG FEUERBACH
}

\author{
Renato Almeida de Oliveira ${ }^{1}$
}

Resumo: O presente artigo pretende apresentar as filosofias de Bruno Bauer, Max Stirner e Ludwig Feuerbach, em especial suas ideias acerca do homem e da religião. Entendemos que tais pensadores foram, durante muito tempo, na história do pensamento ocidental, relegados ao esquecimento, especialmente devido à crítica de Marx aos mesmos. A maior dificuldade em desenvolver esta pesquisa foi o acesso à bibliografia dos autores em questão. Porém, procuramos realizar uma leitura imanente das obras que tivemos acesso, bem como de pesquisadores renomados sobre o movimento neohegeliano.

Palavras-chave: Homem, Religião, Neohegelianos.

Abstract: This article aims show the philosophies of Bruno Bauer, Max Stirner and Ludwig Feuerbach, especially his ideas about man and religion. We understand that these thinkers were, for a long time in the history of Western thought, relegated to oblivion, especially after the Marx's critique of the same. The greatest difficulty in developing this research was access to the bibliography of the authors in question. However, we tried to perform an immanent reading of the works which we had access, as well as from renowned researchers on neohegeliano movement.

Keywords: Man, Religion, Neohegelian.

\section{Introdução}

Com a morte de Hegel, houve uma disputa entre os seus seguidores para saber qual o verdadeiro sentido da filosofia do mestre. Dois grupos disputavam essa interpretação, a saber, os hegelianos de direita, mais focados no aspecto formal da obra de Hegel, e os jovens hegelianos de esquerda, que viam em Hegel um filósofo revolucionário. Deste grupo faziam parte pensadores diversos intelectuais alemães, dentre os quais destacamos Edgar Bauer, seu irmão Bruno Bauer, David F. Strauss,

\footnotetext{
${ }^{1}$ Professor Assistente do Curso de Filosofia da Universidade Estadual Vale do Acaraú - UVA. Doutorando em Filosofia pelo Programa de Pós-Graduação em Filosofia da Universidade Federal do Ceará - UFC.
} 
Ludwig Feuerbach, Arnold Ruge, Moses Hess, Max Stirner, Friedrich Engels, Karl Marx. Todos estes pensadores estavam engajados na transformação da realidade alemã. Cada um formulou sua teoria para contribuir com essa transformação.

Foi com a publicação da obra $A$ vida de Jesus (1835), de Strauss, que o movimento jovem hegeliano de esquerda ganhou força. Nessa obra, Strauss trata os evangelhos em seu caráter histórico, divergindo de Hegel, para quem a historicidade dos livros sagrados era tratada como uma questão secundária, o que importava eram as considerações especulativas sobre os mesmos.

A obra de Strauss, portanto, exacerbou a divisão entre os discípulos de Hegel. Dessa questão teológica, os jovens hegelianos passaram a tratar de questões políticas. Como afirma McLellan (1971, p. 16): “Aqueles debates acerca da religião eram, de todo modo, importantes, como precursores das ulteriores divisões políticas, algumas das quais nunca se libertaram totalmente da influência de suas origens.” Essas discussões políticas foram estimuladas pelas condições sociais e econômicas alemã nos meados do século XIX. A Alemanha era um mosaico de províncias, cada qual com suas leis próprias. Os jovens hegelianos, influenciados pelas ideias sociais dos franceses e pelas ideias econômicas dos ingleses, criaram oposição ao governo da Alemanha com o objetivo de desenvolverem um movimento unificador e emancipatório do país. Isso fez com que o governo prussiano reagisse mediante a censura de todos os periódicos nos quais os jovens hegelianos se expressassem.

Vale ressaltar que as opiniões desses jovens pensadores sobre a política estavam estreitamente relacionadas com suas opiniões sobre a religião. Como eles defendiam que o homem deveria libertar-se da religião, do mesmo modo, o Estado, para poder alcançar a emancipação política, deveria abolir a religião do seu seio. ${ }^{2}$ Quanto ao homem, os neohegelianos de esquerda procuravam libertá-lo de qualquer entidade que lhe fosse estranha, superior, que o pudesse oprimir. Esta foi a perspectiva que guiou os escritos de Bruno Bauer, Max Stirner e Feuerbach, os quais procuraram tematizar o homem como ser autônomo. Para Bauer, o homem era um ser autoconsciente e o desenvolvimento da história nada mais era do que o desenvolvimento dessa

\footnotetext{
${ }^{2}$ Para Feuerbach, por exemplo, abolida a religião do seio do Estado, neste, as forças humanas se unificam e constituem um ser infinito. Muitos homens, muitas forças, constituem uma só força. "O Estado é a soma de todas as realidades; o Estado é a providência do homem. No Estado, os homens representam-se e complementam-se uns aos outros - o que eu não posso ou sei, outro o pode. Não existo para mim, entregue ao acaso da força da natureza; outros existem para mim, sou abraçado por um círculo universal, sou membro de um todo. O Estado verdadeiro é o homem ilimitado, infinito, verdadeiro, completo, divino.” Esta é a concepção de emancipação em Feuerbach. Cf. FEUERBACH, 1988. p. 17.
}

\begin{tabular}{|c|c|c|c|c|}
\hline Revista Qialectus & Ano 2 & n. 4 & Janeiro-Junho 2014 & p. $106-126$ \\
\hline
\end{tabular}


autoconsciência humana. Para Stirner, esse homem era o ser individual, dono de si, sobre o qual nenhuma entidade universal poderia se impor. Já para Feuerbach, o homem era um ser sensível, corpóreo, que reassume sua essência outrora alienada em Deus.

Destacamos em nosso trabalho estes três pensadores porque os mesmos foram, durante muito tempo, preteridos na história do pensamento ocidental, especial depois que Marx desferiu sua crítica contra os mesmos. Porém, grande parte dos filósofos contemporâneos são devedores de Bauer, Stirner e Feuerbach, como, por exemplo, o próprio Marx, que assimila diversos elementos desses pensadores, como a ideia do resgate do homem sensível; Nietzsche, com sua crítica à moral e à religião tradicional, advinda da crítica da religião elaborado pelo movimento neohegeliano; a Teoria Crítica, que bebe nas fontes desse movimento, embora, muitas vezes, de modo indireto, através das obras marxianas. Contudo, é patente o quanto Bauer, Stirner, Feuerbach, bem como os demais pensadores neohegelianos influenciaram a filosofia (as ciências humanas e sociais de uma maneira geral) hodierna. É com senso de justiça com tais pensadores que apresentamos em nosso trabalho, mesmo que de forma sumária, alguns elementos de suas teorias, em especial, a concepção de homem e a crítica à religião.

\section{Bauer e a antropologia da autoconsciência}

Bruno Bauer (1809-1882) foi um teólogo alemão de forte influência hegeliana. Ele estudou Teologia com Hegel pouco antes da morte deste, após a qual foi nomeado, em 1834, professor na Universidade de Berlin. Em virtude de sua formação, Bauer dedicava-se às questões concernentes ao campo da religião, debatendo sobre a veracidade histórica dos evangelhos e sobre a vida de Jesus. Contudo, suas ideias teológicas tinham implicações políticas o que o permitiu posicionar-se ante as questões de seu tempo, como, por exemplo, a relação entre Estado e religião, entre cidadão e homem religioso etc. Suas incursões no campo da política possibilitaram-lhe desenvolver um criticismo radical baseado na destruição das crenças religiosas, isto é, na tentativa de demonstrar o absurdo de toda forma de religião. A religião nada mais é do que a relação da consciência consigo mesma. Bauer considerava suas obras uma exposição da irracionalidade do Cristianismo, em especial do Cristianismo institucionalizado. "Porque o Cristianismo, por revolucionário que fosse nos seus primórdios, agora havia sido ultrapassado e havia se convertido em um obstáculo ao progresso.” (MCLELLAN, 1971, p.63).

\begin{tabular}{|c|c|c|c|c|}
\hline Revista Qialectus & Ano 2 & n. 4 & Janeiro-Junho 2014 & p. $106-126$ \\
\hline
\end{tabular}


Devido às suas ideias críticas a respeito da religião, Bauer foi destituído do seu cargo de professor na Universidade de Bonn, à qual havia sido transferido em 1839, em razão dos confrontos teóricos em Berlin. Esse fato abalou o movimento jovem hegeliano como um todo, e foi decisivo para a vida do jovem Marx dalí por diante. Em virtude desse fato, Bauer dedica-se às publicações de ensaios nos quais critica a relação entre Estado e religião. Um desses escritos, que ficou conhecido por causa da crítica de Marx em 1844, foi o Die Judenfrage (A Questão Judaica). "Bauer estava convencido de que a revolução que ele acreditava ter implantado no plano intelectual iniciaria outra revolução no campo da prática também.” (Ibidem, p. 64). Contudo, suas expectativas foram frustradas devido ao escasso apoio recebido por parte de seus companheiros, também amedrontados com a repressão do governo prussiano. Desse modo, Bauer torna-se um pensador mais moderado, defendendo um criticismo sem fins políticos imediatos.

É quase que consenso entre os intérpretes da filosofia jovem hegeliana reconhecer em Bauer um dos mais notáveis discípulos de Hegel. Conforme David Mc Lellan, o conceito central da filosofia baueriana - a autoconsciência - procedia da obra hegeliana, especificamente da Fenomenologia do Espírito. (Ibidem, p.66). Entretanto, Bauer divergia de Hegel quanto à concepção da dialética. Enquanto para Hegel dialética significa um processo que conduz de um estágio menos determinado para outros cada vez mais determinados, ou seja, ela é um progresso que envolve a totalidade dos momentos, isso porque os momentos posteriores não excluem os anteriores. A esse processo, Hegel denomina de Aufheben. Quer dizer que, na dialética hegeliana, há espaço para os momentos da negatividade e positividade. Para Bauer, ao contrário, a dialética é caracterizada puramente pela negatividade. Isso significa dizer que, em lugar de ser o segundo estado das questões a expressão dos momentos parciais anteriores em sua plenitude, o momento de maior determinação, agora, negava o precedente, e, em casos extremos, era seu rigoroso contrário (cf. Idem). Ou seja, Bauer concebe a dialética como um processo no qual há rupturas extremas, muitas vezes sem espaço para a conservação dos elementos positivos de cada momento anterior. Outro aspecto que distancia Bauer de Hegel diz respeito à relação entre ser e pensar. Enquanto Hegel defendia a unidade indissolúvel de ambos, Bauer dava primazia ao pensamento, especificamente ao pensamento subjetivo.

Contudo, consoante Bauer, no campo da política, a filosofia de Hegel se revelava revolucionária e o mestre era visto como "um revolucionário maior do que

\begin{tabular}{|c|c|c|c|c|}
\hline Revista Qialectus & Ano 2 & n. 4 & Janeiro-Junho 2014 & p. $106-126$ \\
\hline
\end{tabular}


todos os seus discípulos juntos", (BAUER in MCLELLAN, 1971, p. 68) embora somente nos últimos anos de sua vida, Hegel tenha levado a cabo a realização do seu sistema, ou seja, tenha explicitado a verdade de sua filosofia.

\begin{abstract}
"São, precisamente, as discussão dos últimos anos - diz Bauer - as que levaram a cabo a realização do sistema hegeliano." Hegel tratava de separar certos princípios e faculdades, da autoconsciência do homem, porém agora a crítica demonstrava que a autoconsciência abarcava o todo e que era a única força do universo que situa o todo em sua própria órbita. (MCLELLAN, 1971, p. 69)
\end{abstract}

Desse modo, era o autêntico Hegel aquele lido e interpretado pelos jovens hegelianos, o Hegel do ateísmo, da revolução e do republicanismo. Conforme os jovens hegelianos, este era o verdadeiro sentido da filosofia do mestre, escondido por trás da obscura dialética e dos conceitos especulativos de suas obras, mas revelado nos cursos ministrados aos seus alunos. "Porém, nunca foi intenção de Bauer a de dar uma correta exegese do texto hegeliano. Sua pretensão era, melhor, a de assinalar aqueles aspectos do pensamento de Hegel que fossem importantes para o futuro." (Idem).

Quanto ao cristianismo, Bauer mostra-se um crítico ferrenho. Para ele, discordando da teologia tradicional dos séculos anteriores, a religião cristã não pode ser o produto final da história, posto que esta é o progresso dialético da autoconsciência da humanidade. O cristianismo nada mais é do que um momento dessa história, e não a história enquanto tal. Em seu processo, a humanidade atingiu um elevado grau de autoconsciência, de tal modo que alcançou a consciência de sua liberdade. O cristianismo, pelo contrário, submete o homem a Deus e aos dogmas da religião, o que o torna um obstáculo ao progresso e à liberdade do ser humano. Isso é o que Bauer denomina de alienação. Esta consiste na dependência da consciência humana de algo criado por ela.

Segundo Bauer, a religião é uma divisão na consciência, na qual as crenças religiosas chegam a opor-se à consciência como um poder separado [...]. Nesta situação a consciência perde o controle de si mesma, ficando desprovida de todo seu valor, e se sente como aniquilada ante o poder que se lhe opõe. (Ibidem, p. 72).

Com relação aos evangelhos, Bauer sustenta que estes são obras de espíritos criativos e livres e refletem o momento histórico de quem os escreveu. Isso quer dizer que por trás das palavras de cada evangelho há uma personalidade individual que criava determinados elementos, modos de ver os fatos que tornava particular cada escrito. Desse modo,

\begin{tabular}{|c|c|c|c|c|}
\hline Revista Qialectus & Ano 2 & n. 4 & Janeiro-Junho 2014 & p. $106-126$ \\
\hline
\end{tabular}


O cristianismo devia sua origem ao gênio do evangelista original que escreveu o de São Marcos. Este evangelho era uma obra de arte, criada por seu autor. Bauer sustentava que o fato de que uma obra literária fosse também uma obra de arte não só influenciava no conteúdo, mas o criava. A comunidade só era consciente da vida, da morte e da ressurreição de Cristo. Eles queriam mais detalhes e o evangelista os supria e, através daqueles detalhes, interpretava o espírito de seu tempo. (Ibidem, p.70).

Contudo, Bauer reconhece que o cristianismo foi um avanço na história da humanidade, embora tenha sido um avanço condenável. Ele teve um papel determinante na história, pois foi uma fase necessária, um progresso em relação às demais religiões, porque nele o homem se libertava de uma união necessária com a natureza e reconheciase como ser de consciência. Contudo, foi a pior das religiões, pois acreditava na criação divina. Quer dizer, quanto mais o homem aproxima-se da verdade, que está em sua consciência, mais se afasta dela, porque, no cristianismo, a verdade estaria fora do homem, encontra-se em Deus. Desse modo, o cristianismo é um falso reconhecimento do homem. Assim Bauer explica:

\footnotetext{
Estas contradições (quer dizer, as do cristianismo), por antinaturais que possa parecer, não são, todavia, antinaturais; por muito que contradigam a essência do homem, são, entretanto, uma consequiência dela. São contradições contra o homem mesmo, porém se baseiam na natureza e na vocação do homem, o qual, em seu desenvolvimento histórico, entra em contradição consigo mesmo e leva essa contradição ao seu cume, antes que possa alcançar e harmonizá-la consigo mesmo. (BAUER in MCLELLAN, 1971, p. 72).
}

Quanto mais o homem se aproxima de Deus, mais ele afasta-se de si, da humanidade. A sua liberdade como filho de Deus afasta-o de todos os interesses mundanos, das artes, da ciência e de todas as criações da humanidade. É uma liberdade inumana. "Era uma liberdade apresentada como uma dádiva que devia ser recebida com uma incondicional submissão. Esta liberdade era, portanto, uma ilimitada escravidão, sob uma autoridade contra a qual não existia possibilidade alguma de apelação." (MCLELLAN, 1971, p. 73).

A filosofia da autoconsciência de Bauer se apoia em Hegel, na idéia de que a consciência se desenvolve até atingir o grau de totalidade do pensamento. Porém, enquanto para Hegel o motor desse desenvolvimento é o absoluto, Bauer tende a crer que tal motor é o próprio homem como ser autoconsciente. Para Bauer, a autoconsciência sempre aspira a uma universalidade cada vez maior. Ela, portanto, “consiste em seu próprio movimento e encontra sua finalidade e sua identidade apenas nesse movimento." (Ibidem, p. 74).

\begin{tabular}{|l|l|l|l|l|}
\hline Qevista Dialectus & Ano 2 & n. 4 & Janeiro-Junho 2014 & p. 106-126 \\
\hline
\end{tabular}


Essa concepção de autoconsciência só foi possível a Bauer em razão da formulação de seu criticismo, o qual é bastante caro a todo o movimento jovem hegeliano. "O criticismo é a atividade que transforma os objetos em consciência." (Ibidem, p. 75). É mediante o pensamento crítico que os filósofos neohegelianos desenvolvem suas teorias, na tentativa de abarcar a totalidade do real e essa totalidade só é possível por meio da consciência compreendida como a unidade e o poder do universo que rompe com os obstáculos que impedem o desenvolvimento histórico. Em outras palavras, o criticismo é, para os jovens hegelianos, especialmente para Bauer, a verdadeira forma de pensamento, que rompe com as pretensas verdades eternas e resgata o homem, a liberdade e a consciência de si.

\begin{abstract}
Por um lado, o criticismo é a última realização de uma filosofia particular, que deve assim libertar-se a si mesma de um aspecto positivo que ainda limita sua generalidade, e, por outro lado, é a pressuposição sem a qual não podia elevar-se até a generalidade final da consciência. Bauer disse que a história não vem até nós; é nossa própria ação a que deve levar-nos até ela. Esta ação se chama criticismo. (Idem).
\end{abstract}

$\mathrm{O}$ pensamento baueriano a respeito da autoconsciência vem à tona com a discussão Substância versus Autoconsciência. (SOUZA, 1992, p.93). Para Bruno Bauer, quase toda a tradição filosófica ou parte da Substância ou de Deus como o objeto do pensamento humano. “'O começo do saber é um 'imolar-se à substância', que deixa fora toda particularidade e opinião'. Mas esse mesmo saber filosófico, após todo um percurso, deve culminar num poderoso sujeito - 'dissolvedor', 'criador' e 'tirano' - que é a consciência de si." (Ibidem, p.93). Desse modo, o sujeito autoconsciente é o princípio absoluto da Filosofia, e essa autoconsciência torna-se a produtora de todo o conteúdo da realidade; igualmente Substância e Deus nada mais são do que entes que existem apenas na consciência-de-si do homem. Tudo o que parecia distinto do homem, objetivo e superior a ele, adquire ilegitimidade e torna-se momento do desenvolvimento da autoconsciência. 'Com esse novo passo, a subjetividade ou eu renasce como 'tudo', tendo apenas imolado sua finitude e limitação iniciais ao mergulhar na universal substância.” (Ibidem, p. 94). Essa concepção é claramente uma crítica à filosofia hegeliana do Absoluto. Contudo, Bauer reconhece que, no fim do processo dessa mesma filosofia, o sujeito readquire o seu estatuto central. Na filosofia de Hegel, o sujeito, de início, é desprovido de sua autonomia e torna-se um mero momento do Absoluto, ou seja, ele só encontra-se consigo, só atingia a autoconsciência inserido no

\begin{tabular}{|c|c|c|c|c|}
\hline Revista Qialectus & Ano 2 & n. 4 & Janeiro-Junho 2014 & p. $106-126$ \\
\hline
\end{tabular}


processo de desenvolvimento do Espírito. Porém, ao termo desse processo, Hegel realiza uma inversão e restitui o poder da autoconsciência do eu. Em suma:

\begin{abstract}
É assim que agora o eu ou sujeito individual universal é tudo, e a ele pertence a universalidade antes atribuída à substância. Sua imersão ou entrega a esta última, pelo fato de diluir a oposição-separação com relação ao universal (i.e., de suprimir de certo modo a objetividade deste), acaba resvalando para uma "absorção" da universidade pelo eu. Essa subjetividade "alargada" pode agora ser reconhecida como aquilo que "desenvolve a partir de si toda objetividade". E que, como uma verdadeira chama, pode consumir "todas as determinações objetivas e tudo o que está positivamente estabelecido". É verdade que, para que isso acontecesse, a subjetividade finita originária - a consciência individual comum - teve antes de "imolar-se" à substância. Mas, como vimos, esta apenas devora a finitude daquela, para em seguida entregar-se à consciência de si infinitizada. (Ibidem, p. 94).
\end{abstract}

O que podemos observar é que Bauer estava interessado pela realidade humana, com a essência e a felicidade do homem. As suas críticas à religião e a qualquer forma de filosofia da substância ou do absoluto fora do sujeito é uma tentativa de resgatar o homem em sua autonomia, o homem autoconsciente. Esse resgate realizase mediante o pensamento crítico. A Crítica que se faz prática deve corresponder às necessidades do gênero humano:

\begin{abstract}
a ação é inevitável, enquanto é oposição prática e isso não só a título de reflexão ou de um modo indireto. Não, um princípio teórico deve converterse imediatamente em um ato prático [...] a destruição do que existe deve ser o objetivo principal, portanto, a filosofia deve trabalhar também no campo político e [...] atacar as situações existentes. (MCLELLAN, 1971, p.77).
\end{abstract}

Portanto, posto fim a qualquer forma de ser independente da consciência humana, o homem deve encontrar-se consigo mesmo no Estado, a esfera de sua autorealização. O Estado é a manifestação da liberdade humana, pois é o produto do desenvolvimento histórico da consciência. Nesta perspectiva, o Estado deve abandonar toda forma de religião, haja vista esta fragmentar o homem. A experiência que Bauer tem da relação entre Estado e religião é o caso específico do Estado prussiano, no qual a religião cristã imperava. Assim, Bauer se opõe ao cristianismo especialmente porque este separa os homens uns dos outros e de sua verdadeira essência, qual seja, a existência universal, autoconsciente. O Estado religioso é um Estado imperfeito. Contudo, o Estado politicamente emancipado é a mais alta expressão da liberdade humana, e afirma: "Se o Estado nos rechaça, nós, entretanto, não rechaçamos o Estado, mas manteremos firmemente o princípio do Estado como o mais alto que existe. A análise final mostrará que elegemos a melhor parte.” (Ibidem, p.83).

\begin{tabular}{|c|c|c|c|c|}
\hline Revista Qialectus & Ano 2 & n. 4 & Janeiro-Junho 2014 & p. $106-126$ \\
\hline
\end{tabular}




\section{Max Stiner e a Antropologia do Eu}

Kaspar Schmidt, verdadeiro nome de Max Stirner, ingressou na Faculdade de Filosofia da Universidade de Berlim aos 20 anos, onde conheceu a filosofia de Hegel, da qual se tornou discípulo. Em 1844, publica sua única obra, intitulada $O$ único e a sua propriedade (Der Einzige und sein Eigentum). Sua produção foi estimulada pelo grupo dos jovens intelectuais radicais (os livres, como eram conhecidos), formado por Bruno Bauer logo após sua destituição da Universidade de Bonn.

Embora autor de uma única obra, Stirner escreveu artigos para diversos periódicos, dentre eles a Gazeta Renana, na qual publicou um ensaio sobre a educação do eu e outro sobre o sujeito hegeliano. $O$ Único é uma obra que tem forte influência de Hegel, um livro que apresenta o espírito do movimento jovem hegeliano, ao repudiar toda forma de religiosidade e sistemas filosóficos. Entretanto, ele é considerado o último dos neohegelianos de esquerda, pois enquanto estes buscavam um princípio universal que pudesse substituir o Absoluto hegeliano - fosse a humanidade, a sociedade sem classes, o Estado, entre outros - Stirner não pretendia criar nenhum universal, mas apenas o Eu, o indivíduo proprietário de si.

José Crisóstomo de Souza resume a "biografia" do indivíduo stirneriano com as seguintes palavras: "É através do desenvolvimento do seu espírito que o indivíduo se sobrepõe ao 'mundo das coisas'; que primeiro se afirma e se descobre a si mesmo. Mas é nesse mesmo movimento que novamente ele se perde, agora no 'mundo do espírito." " (SOUZA, 1993, p. 15). Isso quer dizer que, em Stirner, o processo de constituição da individualidade humana ocorre mediante um libertar-se de tudo o que esteja para além do homem, libertar-se de tudo o que pode subjugá-lo. O homem é o Único, o euproprietário.

De fato, o próprio Stiner afirma, no primeiro capítulo da obra $O$ único e a sua propriedade, que a vida humana consiste na busca do auto-encontro e da autoconquista. Ele vê-se lançado no mundo sem nenhuma orientação. Neste mundo, ele defronta-se com objetos que se rebelam contra sua própria existência. “Assim sendo, e porque tudo está centrado em si mesmo e ao mesmo tempo entra em colisão com todo o resto, a luta pela auto-afirmação é inevitável.” (STINER, 2009, p. 15).

Stiner descreve o processo de desenvolvimento da individualidade ou do Eu. Enquanto criança, o homem está preso ao mundo das coisas, mede força com os objetos materiais para daí sentir-se seguro no mundo. Pouco a pouco, a criança vai desvendando

\begin{tabular}{|c|c|c|c|c|}
\hline Revista Qialectus & Ano 2 & n. 4 & Janeiro-Junho 2014 & p. $106-126$ \\
\hline
\end{tabular}


tudo o que antes era inquietante e assustador e nesse momento "já não recuamos, atemorizados, diante daquilo que nos incutia medo e respeito, mas ganhamos coragem." (Ibidem, p. 16). Ao desvendar a razão de ser das coisas e ver-se como superior diante delas, atingindo um estado de ataraxia, o homem descobre-se como ser de espírito. Agora ele não mais travará uma luta com as coisas, mas com a razão. Essa luta contra a razão dá início a uma nova fase da existência humana: a juventude. É a fase do encontro do homem consigo mesmo, isto é, a fase do espírito.

Espírito é o nome do primeiro encontro com nós mesmos, da primeira desdivinização do divino, ou seja, do inquietante, dos fantasmas, dos "poderes superiores". Agora o novo sentimento de juventude, este sentimento que nos confirma em nós, não se deixa impressionar facilmente: o mundo caiu em descrédito porque estamos acima dele, somos espírito. (Ibidem, p. 17).

Nesta fase espiritual do homem, tudo o que é terreno é desprezado, inclusive os demais homens. É uma idade idealista, na qual tudo o que vale são as "coisas do espírito". Passa-se a um ponto de vista celestial e a um comportamento espiritual.

Enquanto a criança esbarrava nas leis do mundo, naturais, as ações do jovem esbarram nas objeções do espírito, quer dizer, na consciência. É este quem dita as regras de ação. Como outrora o homem era guiado pelas ordens dos pais, agora ele abandonase aos mandamentos do pensamento.

Ao descobrir-se como ser espiritual, a tarefa do homem é buscar a riqueza de espírito, já que sua espiritualidade não é perfeita e acabada. Todavia, nessa condição, o homem volta a perder-se, tornando-se um súdito do espírito perfeito ao qual aspira. Diz Stiner: "Mas, com isso, eu, que mal tinha acabado de me encontrar como espírito, volto logo a perder-me, inclinando-me perante o espírito perfeito, que não é meu, mas de um além, e caio assim em um sentimento de vacuidade." (Ibidem, p.19).

Esse sentimento de vacuidade, de perda, que o homem sente, ao descobrir-se como espírito imperfeito, dá ensejo para que se comece uma terceira e nova fase de sua existência, a vida adulta. Nesta, o homem retorna ao mundo e olha-o tal como ele é, não lhe interessando moldá-lo de acordo com seus ideais. Enquanto permanece como ser espiritual, o homem perde de vista o campo da ação e ao tentar encontrá-lo tenta apenas concretizar nele seus pensamentos. É o homem como corpo, como espírito corpóreo que pode encontrar em si mesmo o prazer. O jovem só podia encontrá-lo no espírito perfeito, universal, absoluto, mas ao qual não podia ascender. O adulto encontra uma satisfação total do seu ser, uma satisfação de todo o indivíduo. Seus interesses passam a

\begin{tabular}{|c|c|c|c|c|}
\hline Revista Qialectus & Ano 2 & n. 4 & Janeiro-Junho 2014 & p. $106-126$ \\
\hline
\end{tabular}


servir ao seu ego. "Os rapazes só tinham interesses não intelectuais, isto é, sem pensamentos nem idéias; e os jovens, apenas interesses espirituais; o homem tem interesses que se prendem com o corpo, pessoais, egoístas.” (Ibidem, p. 21). Agora o homem encontra-se como eu-proprietário, isto é, como criador das idéias, dos pensamentos, e não mais como seu objeto a serviço do espírito.

\footnotetext{
$\mathrm{Na}$ fase dos espíritos, fiquei cheio de idéias até por cima da cabeça, de onde elas, aliás, tinham nascido: como fantasias febris, giravam à minha volta e assustavam-me com seu terrível poder. As idéias tinham ganho corpo em si mesmas, eram espectros, tal como Deus, o imperador, o papa, a pátria etc. Se eu destruir sua corporalidade, assimilo-a à minha e digo: só eu tenho corpo. E então tomo o mundo como aquilo que ele é para mim, como o meu mundo, a minha propriedade: eu sou a referência única de tudo. (Ibidem, p. 21-22).
}

O eu-proprietário rejeita o mundo das idéias, toda realidade extra-mundana que possa exercer algum poder sobre ele. O homem na fase adulta é o egoísta que põe seus interesses pessoais acima de qualquer coisa, seja ideal, seja material.

O que se segue, na obra stirneriana acima mencionada, não passa da tentativa do neo-hegeliano em determinar progressivamente as três fases da vida humana. No capítulo 2, por exemplo, Stirner explicita como as fases da infância e da juventude, a primeira presa ao "mundo das coisas" e a segunda presa ao "mundo do espírito", revelam-se, respectivamente, na antiguidade e na modernidade. Ele assevera que os Antigos deveriam ser propriamente chamados de "crianças", pois, para eles, a verdade era o mundo, ou seja, "os Antigos viviam na convicção de que o mundo e as relações mundanas (por exemplo, os laços de sangue naturais) eram o verdadeiro, ante o qual o eu impotente teria de se vergar." (Ibidem, p. 24). É no mundo cristão que a ideia da verdade do mundo é negada. Para o cristão, o mundo é desprovido de valor, é pura mentira. O que tem valor é o espírito. Os homens devem aspirar as coisas espirituais, pois nelas está a verdade.

Foi o próprio mundo antigo, todavia, quem gestou sua negação e trabalhou "no sentido de transformar sua verdade em mentira." (Ibidem, p. 25). Foram os sofistas os iniciadores dessa inversão. Para eles, o espírito é a verdadeira arma do homem contra o mundo. Eles exortavam as pessoas a usarem o entendimento para superarem as artimanhas, as determinações da realidade. Porém, o espírito, na compreensão sofista, ainda não é puro, absoluto, mas é um meio de confronto com o mundo. Sócrates é quem torná-lo-á absoluto, mediante a purificação do coração.

De fato, se o coração não se libertasse de seus impulsos naturais, mas permanecesse dominado pelos conteúdos mais contingentes é, em sua avidez. sem crítica, sujeito ao total domínio das coisas, não sendo mais que um vaso

\begin{tabular}{|c|c|c|c|c|}
\hline Revista Qialectus & Ano 2 & n. 4 & Janeiro-Junho 2014 & p. $106-126$ \\
\hline
\end{tabular}


para os mais diversos apetites, então o livre entendimento acabaria inevitavelmente a serviço do "mau coração", justificando tudo aquilo que o coração corrupto desejasse. (Idem).

O homem, portanto, na orientação socrática, não deve apenas utilizar o entendimento, mas saber qual causa ele está a servir (ação moral). Segundo Stirner, essa é a segunda fase da libertação intelectual da antiguidade.

Os céticos levaram a cabo a obra iniciada por Sócrates, esvaziaram o coração humano de qualquer conteúdo, de qualquer forma de interesse mundano e criaram as condições para a sua total espiritualização.

\begin{abstract}
Enquanto o ser humano se deixar envolver pelo movimento do mundo e por sua relação com ele - e isso acontece até o fim da Antigüidade, porque seu coração ainda tem de lutar pela libertação das peias mundanas - não será ainda espírito, porque o espírito é sem corpo e não tem ligação com o mundano e com o corpóreo: para ele, não existe mundo nem dependência da natureza, mas tão-somente espiritualidade e relações espirituais. Por isso o homem teve de tornar-se primeiro frio e despreocupado, completamente independente, tal como a cultura cética o apresenta, tão indiferente em relação ao mundo que nem sua derrocada o afetava, antes de poder sentir-se privado do mundo, ou seja, espírito. É este o resultado do gigantesco trabalho dos Antigos: o ser humano passa a tomar consciência de si como ser sem ligações e sem mundo, como espirito. (Ibidem, p. 28).
\end{abstract}

Essas duas fases da libertação antiga, o entendimento e o coração, apresentamse de forma acabada no cristianismo. Nada mais adequado, haja vista o cristianismo se ocupar exclusivamente com o espiritual. Até mesmo quando se volta para o mundo, o cristão está a procurar as marcas do espírito (de Deus). O seu prazer, a sua satisfação, está no espírito, no pensamento. Por isso as adversidades do mundo não o perturbam. Sua ação é sempre um pensar. Para Stirner, é esse modo espiritual de encarar a existência que os modernos herdaram do mundo cristão. Para eles, o homem é pensamento. "Penso, logo existo" (Descartes).

Na modernidade, a vida é apartada das coisas. O homem "não vai já buscar seu alimento na natureza, mas 'vive apenas de pensamentos', e por isso deixou de ser um 'viver' para se tornar... um pensar." (Ibidem, p. 31).

Contudo, Stirner mostra como os pensamentos tornam-se alheios ao seu criador, o homem. Os homens passaram a ser dominados pelo espírito. Nesse ínterim, Stirner critica os filósofos modernos por estes terem criado um mundo de idéias independentes do homem. É o caso dos pensadores críticos alemães e dos conhecidos filósofos idealistas alemães. O que todos fizeram foi transformar objetos existentes em objetos pensados, os quais passaram a se impor de modo independe ao indivíduo.

\begin{tabular}{|c|c|c|c|c|}
\hline Revista Qialectus & Ano 2 & n. 4 & Janeiro-Junho 2014 & p. $106-126$ \\
\hline
\end{tabular}


O intuito central da filosofia de Max Stirner é abolir toda entidade que esteja acima, independente, e que subjugue o indivíduo, o eu. Isso ocorre na fase adulta da vida humana. Para Stirner, somente quando o indivíduo reduzir o espírito a uma mera fantasmagoria, a um mero ente abstrato, sem vida, e não mais admitir seu poder sobre si, ele poderá tornar-se o verdadeiro eu, usando de seus próprios interesses como bem lhe agrada. Portanto, o verdadeiro homem, na perspectiva stirneriana, é o homem egoísta, individualista, criador de sua causa, enfim, o proprietário do mundo das coisas e do espírito.

$\mathrm{Na}$ segunda parte de $O$ único e a sua propriedade, Stirner apresenta essa existência individualista do homem. Este é a sua própria referência. Sua liberdade começa dentro de si e só depende de si. Ora, a liberdade consiste sempre em livrar-se de algo que o indivíduo não quer, mas não numa forma abstrata de ser livre, ou seja, numa liberdade absoluta. Há coisas das quais o eu não quer se ver livre, coisas que lhe satisfazem. As coisas das quais pretendem se livrar é sempre em vista do próprio bem do indivíduo. Isso quer dizer que é a individualidade, o eu (egoísta) que é tomado como medida na busca da liberdade. A conclusão de Stirner é que não existe a liberdade fática, real. O que existe é apenas o eu. Portanto, o homem deve torna-se proprietário de si, saber-se, conhecer seus anseios, o que realmente deseja. É somente na posse de si que o homem é livre. Por isso, Stirner afirma: "Não tenho nada contra a liberdade, mas desejo que tenhas mais do que liberdade; o que tu precisas não é apenas te libertar do que não queres, mas ainda ter aquilo que queres, ser não apenas 'homem livre', mas também 'o eu-proprietário.”' (Ibidem, p. 202).

Há, portanto, uma diferença entre liberdade e individualidade, ou que Stirner chama de "singularidade-do-próprio". A liberdade está sempre referida a algo externo. Podemos ser livres de muitas coisas que não nos agrada, mas não de tudo. Por isso, "a liberdade vive apenas no reino dos sonhos!” (Ibidem, p. 204). Já a singularidade-dopróprio é a própria existência e essência do eu.

\footnotetext{
Meu próprio (mein eigen), sou-o em cada momento e em todas as circunstâncias, desde que saiba ter-me e não me entregar aos outros. Não posso verdadeiramente querer ser livre porque isso não é coisa que eu possa fazer ou criar: só posso desejá-lo e... aspirar a isso, porque se trata de um ideal, de um fantasma. Os grilhões da realidade deixam a cada momento marcas profundas em minha carne. Mas eu continuo a ser meu. Escravo de um senhor, só penso em mim e em minha vantagem; é certo que suas pancadas me atingem, não estou livre delas, mas só as suporto para benefício meu [...] Contudo, como não me perco de vista, nem a mim nem a meu interesse, não deixo passar a próxima boa oportunidade para pisar o senhor de escravos. Minha libertação dele e de seu chicote será então apenas a
}

\begin{tabular}{|l|l|l|l|l|}
\hline Qevista 2 ialectus & Ano 2 & n. 4 & Janeiro-Junho 2014 & p. 106-126 \\
\hline
\end{tabular}


consequência de meu egoísmo anterior [...] Porém eu era eu próprio, meu próprio, completamente, por dentro e por fora. (Ibidem, p. 204).

Se o indivíduo realmente quer se ver livre, a única fonte de tal liberdade será o eu, que subsiste a tudo e é pressuposto por tudo. Por exemplo, se o homem obedece aos mandamentos de Deus, é pelo bem do eu e por sua salvação que o faz. É como individualidade única, eu-proprietário, que o homem bane qualquer poder superior e estranho a si, quer dizer, no "único" é dissolvido o mundo do espírito, dos pensamentos absolutos. Do mesmo modo, o único abole o "mundo das coisas". Sendo assim, ele é a síntese entre ambos, ou seja, é nele que a oposição entre real e ideal tem seu termo.

\section{Feuerbach e a Antropologia da Sensibilidade}

O debate de Feuerbach com a Teologia e a Filosofia Especulativa é o pano de fundo frente ao qual se desenvolve sua antropologia da sensibilidade. Tanto a Teologia quanto a Filosofia Especulativa moderna, especialmente a hegeliana, à qual Feuerbach dedica boa parte das suas objeções, conceberam o homem como um ser essencialmente espiritual. Ao criticar essas concepções, o filósofo de Landshut resgata o homem real, sensível, cujo fundamento é a natureza. Esta, para ele, possui autonomia e primazia ante a razão. Nessa perspectiva, o homem não pode ser pensado fora da realidade material, pois é visto como um ser natural, sensível.

Feuerbach pretende realizar uma reforma da filosofia, pondo no lugar da especulação, das abstrações filosóficas dos sistemas modernos, cujas formulações não passam de uma racionalização da Teologia, de querelas banais, de arbitrariedades, uma nova filosofia que corresponda às exigências da humanidade, uma filosofia com força positiva, por ser nagativa, isto é, uma filosofia nova que traz em si a negação dos diversos sistemas filosóficos precedentes. Uma filosofia que não corresponde às necessidades históricas dos homens é uma reação ao desenvolvimento da própria humanidade. Conforme Feuerbach, os sistemas filosóficos da modernidade foram uma espécie de reação, mostraram-se insuficientes, porque não corresponderam às reais exigências da humanidade; tais sistemas restringiram-se a especulações sobre realidades abstratas, extramundanas. A verdadeira filosofia, nos moldes como é concebida pelo materialismo feuerbachiano, é aquela que tem a exigência do futuro, que é movimento para a frente, que acompanha as exigências dos homens concretos; (FEUERBACH, 1988, p.13-14) é aquela que penetra no coração do homem (Ibidem, p. 14), que torna-se

\begin{tabular}{|c|c|c|c|c|}
\hline Revista Qialectus & Ano 2 & n. 4 & Janeiro-Junho 2014 & p. $106-126$ \\
\hline
\end{tabular}


humana. O coração simboliza a sensibilidade; nesse sentido, a verdadeira filosofia funda-se na sensibilidade (na natureza e no homem real) e não na abstração (no espírito e no homem teórico).

O homem moderno, segundo Feuerbach, é o homem prático, com interesses diversos daqueles religiosos; é o homem da ciência, da arte e da indústria. Novos homens exigem uma nova filosofia, pois esta é produto daqueles. Esses novos homens fundam "uma época nova, fundam a necessidade de uma filosofia nova, não mais cristã" (Ibidem, p. 14-15), isenta das especulações teológico-filosóficas. Desse modo, Feuerbach afirma:

Para o lugar da fé, entrou o descrença; para o lugar da Bíblia, a razão; para o lugar da religião e da igreja, a política; a terra substituiu o céu, o trabalho substituiu a oração, a necessidade material o inferno, o homem o cristão. (Ibidem, p. 16).

Feuerbach, portanto, mostra que o divino (Deus) foi substituido pelo mundano (homem) e, com isso, funda-se o princípio supremo sobre o qual se ergue o novo espírito da humanidade. Esse princípio é o ateísmo, que significa o abandono de qualquer entidade absoluta distinta do homem e o reatamento dos laços que ligam os homens entre si. Feuerbach pretende fazer com que o homem retome a sua consciência genérica, a qual lhe foi alienada pela Teologia. Esta elevou as determinações humanas à abstração e, com isso, criou um ser espiritual distinto do homem, seu criador, do qual passa, supostamente, a depender a sua existência. Na religião, esse ser espiritual, supremo, providencia tudo o que a humanidade necessita. "Por isso, o homem não precisa do homem; tudo o que ele deve receber de si ou dos outros recebe-o imediatamente de Deus. Confia em Deus, não no homem." (Ibidem, p. 16).

Ao pretender retirar a religião da vida humana, Feuerbach confia aos indivíduos politicamente organizados (o Estado), os quais se reunem entre si pela razão de que não mais crêem em nenhum Deus, o papel de providenciador dos meios necessários à sobrevivência da humanidade. Dessa forma, o Estado se origina da desconfiança em Deus e da crença do homem como Deus do homem. Daí pode-se compreender o apelo de Feuerbach para que a política torne-se a religião da humanidade.

No Estado, as forças do homem separam-se e desenvolvem-se para, através desta separação e sua reunificação constituírem um ser infinito; muitos homens, muitas forças, constituem uma só força. O Estado é a soma de todas as realidades; o Estado é a providência do homem. No Estado, os homens representam-se e complementam-se uns aos outros - o que eu não posso ou sei, outro o pode. Não existo para mim, entregue ao acaso da força da

\begin{tabular}{|l|l|l|l|l|}
\hline Qevista 2 ialectus & Ano 2 & n. 4 & Janeiro-Junho 2014 & p. 106-126 \\
\hline
\end{tabular}


natureza; outros existem para mim, sou abraçado por um círculo universal, sou membro de um todo. O Estado verdadeiro é o homem ilimitado, infinito, verdadeiro, completo, divino. (Ibidem, p. 17).

Chego, desse modo, ao âmago da filosofia feuerbachiana, que pode ser sintetizada na assertiva a teologia é antropologia (cf. Ibidem, p. 19). Todos os atributos de Deus nada mais são do que atributos humanos tornados universais e postos acima do homem. Desse modo, Deus deixa de ser a gênese do homem e torna-se seu produto. É nessa inversão que consiste a crítica de Feuerbach à Teologia. Esta, enquanto teorização das religiões, tem a pretenção de elaborar uma concepção de mundo que torne compreensível ao homem a realidade que o circunda e a sua posição nesta. Tal concepção é fundada em um ser transcendente, isto é, a Teologia sustenta que foi Deus quem criou e mantém o universo, de uma forma livre e direta. Nesse sentido, para o teólogo, "o mundo e o homem atestam que não têm em si mesmos nem seu princípio primeiro nem seu fim último, mas que participam do ser em si, que é sem origem e sem fim.” (CATECISMO DA IGREJA CATÓLICA, 2001, p. 24).

Em suas Preleções sobre a Essência da Religião, Feuerbach expõe sua doutrina nos seguintes termos: "teologia é antropologia, ou seja, no objeto da religião se expressa nada mais do que a essência do homem, ou: o deus do homem não é nada mais que a essência divinizada do homem." (FEUERBACH, 1989, p. 23).

Disso podemos apreender, por exemplo, a diferença entre politeísmo e monoteísmo. O primeiro é a crença pagã em vários deuses, enquanto o segundo é a crença judaico-cristã em um único Deus. Entretanto, essa diferença é simplesmente a diferença entre o homem pagão e o cristão. O pagão é nacionalista, portanto, limitado; já o cristão é cosmopolita, daí seu deus ser universal, um único deus para toda a humanidade. (Ibidem, p. 24). Portanto, “o deus cristão, assim como o pagão, surgiu no homem a partir do homem. É apenas um deus diverso do deus pagão porque também o homem cristão é diverso do pagão." (Ibidem, p. 25).

Todavia, Feuerbach reconhece que, em sua doutrina antropológica crítica, havia uma lacuna que deveria ser preenchida para evitar-se mal entendidos. Ele percebeu que havia ignorado uma realidade fundamental, anterior ao próprio homem: a natureza. Dessa forma, em A Essência do Cristianismo (1841), Feuerbach faz surgir do nada a essência do homem, fazendo parecer que ele tem em si mesmo o fundamento de sua existência. Porém, ao reconhecer seus limites, o filósofo afirma que "o homem não se fez por si mesmo, que ele é um ser dependente, surgido, logo tendo fora de si o

\begin{tabular}{|c|c|c|c|c|}
\hline Revista Qialectus & Ano 2 & n. 4 & Janeiro-Junho 2014 & p. $106-126$ \\
\hline
\end{tabular}


fundamento de sua existência, mostrando a si mesmo e sobre si um outro ser. " (Ibidem, p. 26). Esse outro ser é a natureza. Sem ela, a existência humana torna-se impossível e sua essência não pode ser concebida.

Com este salto, Feuerbach não mais explica a realidade, deus ou a religião com base no homem, mas a partir da natureza. Nesta perspectiva, diz ele que, se antes havia resumido sua filosofia na sentença a teologia é antropologia, agora esta síntese ampliase, pois nela é acrescentada a fisiologia, ou seja, que Deus pode ser explicado por meio das leis físicas naturais. Dessa forma, Feuerbach defende a natureza como fonte originária de tudo. Portanto, ela não foi criada nem tampouco é conduzida por um ser do além, mas por suas próprias leis físicas e químicas; ela possui uma mecânica própria, uma ordem imanente, dentro da qual está contida também a desordem. É neste contexto de tensão entre ordem e desordem, de relação de forças que surge e desenvolve-se a vida. Feuerbach aparece como o filósofo que resgata a natureza da condição de criatura à condição de ser primeiro, incriado e necessário. Assim, a natureza não precisa de nenhum outro ser para organizá-la, um ser além dela, que, na verdade, para o filósofo, não existe: “é conseqüência de minha doutrina que não existe nenhum Deus, ou seja, nenhum ente abstrato, supra-sensível, diverso da natureza e do homem, que decide sobre o destino do universo e da humanidade a seu bel-prazer." (Ibidem, p. 29).

Do mesmo modo que a Teologia, a Filosofia Especulativa põe fora do homem a sua essência e concede um caráter objetivo ao seu pensamento. Por isso que Feuerbach a denomina de Teologia racionalizada (Ibidem, p. 39) ou Teologia especulativa. (Ibidem, p. 19). A filosofia hegeliana é, para Feuerbach, um mero movimento do puro conceito, sendo alheia ao ser sensível. Na filosofia de Hegel, a realidade não transcende o campo do abstrato, realizando um movimento em torno do pensamento lógico. A imediaticidade do mundo restringe-se apenas a uma determinação da idéia.

Em Hegel, a natureza, a sensibilidade, aparecem somente como determinações mais pobres do espírito; a matéria torna-se predicado do absoluto. A filosofia de Feuerbach, ao contrário, inverte a relação sujeito-predicado como exposta pela Filosofia Especulativa. Sobre esse aspecto, o seu objetivo é "fazer sempre do predicado o sujeito e fazer do sujeito o objeto e princípio - portanto, inverter apenas a filosofia especulativa de maneira a termos a verdade desvelada, a verdade pura e nua." (Ibidem, p. 20). Isto é, a natureza, a sensibilidade tornam-se o sujeito, sem o qual o Espírito absoluto não passa de um simples nome.

\begin{tabular}{|c|c|c|c|c|}
\hline Revista Qialectus & Ano 2 & n. 4 & Janeiro-Junho 2014 & p. $106-126$ \\
\hline
\end{tabular}


Na Fenomenologia do Espírito, Hegel apresenta a arte, a religião e a filosofia como manifestações e realizações do Espírito absoluto. Feuerbach questiona-o: como é possível separar a arte, a religião e a filosofia do homem real, ou seja, da sensação, da fantasia, da intuição e da pensamento humano? Hegel realiza essa separação e, ao fazêla, ele retorna, segundo Feuerbach, ao antigo ponto de vista da Teologia, colocando o Espírito como um ser distinto do homem, “como um fantasma de nós mesmos existindo fora de nós." (Ibidem, p. 22). E Feuerbach conclui que esse espírito é o espírito defunto da Teologia que assombra a filosofia hegeliana como um fantasma.

A arte é um exemplo que reforça a tese feuerbachiana de que o Espírito absoluto nada mais é do que uma abstração das determinações humanas. A arte é um produto dos sentimentos humanos, ou seja, das suas inquietações provenientes do confronto com a realidade; portanto, ela revela que a verdadeira vida é a vida neste mundo. (Ibidem, p. 23). Quando expressa o divino por meio de suas obras, o artista apenas faz refletir nestas as qualidades do ser determinado e real, do homem. Os gregos, por exemplo, "elevaram-se a plenitude da arte plástica unicamente porque viram na forma humana, de um modo incondicional e sem hesitação, a forma suprema, a forma da divindade." (Idem).

Portanto, a filosofia especulativa de Hegel realiza uma abstração do homem e da natureza. Ao contrário, Feuerbach propõe que a filosofia vá à natureza, à sensibilidade, resgatando o homem real. Desse modo, a sensibilidade torna-se o ponto de partida da filosofia. Partindo dessa idéia, Feuerbach desenvolve uma crítica ao começo da filosofia de Hegel (cf. CHAGAS, 2005).

Hegel iniciou a sua filosofia sistemática com o indeterminado, o imediato, o ser puro, que não exige nenhum pressuposto. Este ser puro é positividade, como unidade de todo ser, afirmação de toda determinidade. Todavia, ele não é determinado e, enquanto tal, é negatividade. Portanto, esse ser inicial é não-ser. Cria-se, com isso, uma tensão dialética entre ser e não-ser, a com base na qual o sistema se desenvolve. Dessa tensão, surge o terceiro elemento da tríade inicial da filosofia hegeliana, o devir. Este é, para Hegel, a verdade do ser e do não-ser, o movimento dialético de um para o outro, desfazendo, dessa forma, a indeterminidade de ambos (cf. Idem).

Feuerbach vê, no começo dessa filosofia, um movimento do puro pensar abstrato, permanecendo o ser real olvidado, aparecendo apenas como emanação do espírito. Por esse motivo, Feuerbach critica Hegel, ao afirmar que:

\begin{tabular}{|c|c|c|c|c|}
\hline Revista Qialectus & Ano 2 & n. 4 & Janeiro-Junho 2014 & p. $106-126$ \\
\hline
\end{tabular}


O começo da filosofia não é Deus, não é o absoluto, nem o ser como predicado do absoluto ou da idéia - o começo da filosofia é o finito, o determinado, o real. O infinito Não pode pensar-se sem o finito. Podes tu pensar, definir a qualidade, sem pensar numa qualidade determinada? Por conseguinte, o primeiro não é o indeterminado, mas o determinado, pois a qualidade determinada nada mais é do que a quealidade real; a qualidade real precede a qualidade pensada. (FEUERBACH, 1989, p. 24-25)

A verdade, para Hegel, não está no mundo sensível. Diante disso, Feuerbach retruca: no caso do aqui da certeza sensível, o ser sensível, embora pereça, permanece, pois o seu perecer traz consigo um outro ser sensível. Nesse sentido, a natureza nega e, ao mesmo tempo, põe o ser sensível, ou seja, ela "nega constantemente o ser sensível, o singular, mas refuta simultaneamente esta negação, na medida em que ela põe ou cria um outro existente em seu lugar." (CHAGAS, 2006) Desse modo, Feuerbach resgata o status ontológico da sensibilidade.

Visto desse modo, o ser sensível não pode ser considerado como um predicado do espírito ou como um grau mais pobre da consciência. Uma filosofia que assim age jamais poderá formular um conhecimento verdadeiro sobre a real posição do finito. Tal filosofia é uma contradição porque deduz o finito do infinito, o ser da idéia. Essa atitude conduz à negação do infinito, da idéia, pois é como se admitisse que, sem a finitude, o infinito não pode ser. Então, o finito aparece como a verdade do infinito.(FEUERBACH, 1989, p. 24) Mas, como a filosofia especulativa continua afirmando o primado do espírito, cai em contradição, na qual "o finito é a negação do infinito e, por seu turno, o infinito é a negação do finito." (FEUERBACH, 1988, p. 24).

Portanto, para Feuerbach, o filósofo deve introduzir na filosofia o princípio da finitude, da sensibilidade, que se opõe ao pensamento abstrato. Somente com essa introdução é que a Filosofia tornar-se-á irrefutável, não contraditória, verdadeira, e, sobretudo, uma filosofia que corresponderá às necessidades da humanidade.

Do mesmo modo que na Teologia, na qual o homem é a verdade de Deus, porque as determinações de Deus nada mais são do que as determinações humanas elevadas ao universal, na filosofia especulativa, o finito, a sensibilidade, a natureza são as verdades do espírito, do infinito. Por isso, “a filosofia especulativa tornou-se culpada do mesmo erro que a teologia - ter feito das determinações da realidade ou da finidade determinações e predicados do infinito.” (FEUERBACH, 1988, p. 25). É por esse motivo que Feuerbach clama para que a humanidade abandone as especulações abstratas da filosofia moderna e volte-se para a natureza e o homem, pois ambos são os mistérios da filosofia. Desse modo, Feuerbach conclui:

\begin{tabular}{|c|c|c|c|c|}
\hline Revista Qialectus & Ano 2 & n. 4 & Janeiro-Junho 2014 & p. $106-126$ \\
\hline
\end{tabular}




\begin{abstract}
A nova, a única filosofia positiva, é a negação de toda a filosofia de escola, embora dela contenha em si a verdade, é a negação da filosofia como qualidade abstrata, particular, isto é, escolástica [...] ela é o próprio homem pensante - o homem que é e sabe que é a essência autoconsciente da natureza, a essência da História, a essência dos Estados, a essência da religião [...] que sabe que o ser panteísta, que os filósofos especulativos ou, antes, os teólogos separavam do homem, e objetivavam num ser abstrato, nada mais é do que a sua própria essência indeterminada, mas capaz de infinitas determinações. (Ibidem, p. 32-33).
\end{abstract}

Em suma, Feuerbach é o arauto de uma nova Filosofia que realiza a humanização de Deus, transformando a Teologia em Antropologia, concretizando as abstrações religiosas. No tocante à filosofia especulativa, nosso filósofo traduz para uma linguagem materialista, sensualista, as formas abstratas, espiritualistas da especulação, e o faz por meio da negação da filosofia, que é o ápice de toda a modernidade, a filosofia hegeliana. Com essa negação, ele resgata o homem ao seu ser real, isto é, faz que o homem volte a se identificar consigo mesmo.

\title{
Referências Bibliográficas
}

CATECISMO DA IGREJA CATÓLICA. Sagrada Congregação para a Doutrina da Fé Vaticano. 11. ed. São Paulo: Loyola, 2001.

CHAGAS, E. F. A questão do começo na filosofia de Hegel - Feuerbach: crítica ao "começo" da Filosofia de Hegel na Ciência da Lógica e na Fenomenologia do Espírito. In: Revista Eletrônica de Estudos Hegelianos, ano 2, n. 2, jun. 2005. Disponível em: <http://www.hegelbrasil.org/rev02b.htm>. Visitado em: $16 \mathrm{dez} 2006$.

FEUERBACH, Ludwig. A essência do cristianismo. Tradução de José da Silva Brandão. 2. ed. Campinas-SP: Papirus, 1997.

Necessidade de uma reforma da filosofia. In:

Princípios da

filosofia do futuro. Tradução de Artur Morão. Lisboa: Edições 70, 1988.

Preleções sobre a essência da religião. Tradução de José da Silva Brandão. Campinas-SP: Papirus, 1989.

Teses provisórias para a reforma da filosofia. In:

Princípios da

filosofia do futuro. Tradução de Artur Morão. Lisboa: Edições 70, 1988.

MCLELLAN, David. Marx y los jóvenes hegelianos. Traducción de Marcial Suarez. Bercelona: Ediciones Martínez Roca, 1971.

SOUZA, José Crisóstomo de. A questão da individualidade: a crítica do humano e do social na polêmica Stirner-Marx. Campinas: Editora da UNICAMP, 1993.

\begin{tabular}{|l|l|l|l|l|}
\hline Qepista Dialectus & Ano 2 & n. 4 & Janeiro-Junho 2014 & p. 106-126 \\
\hline
\end{tabular}


Ascensão e queda do sujeito no movimento jovem-hegeliano: Hegel, Strauss, Bauer, Feuerbach, Stirner, Marx. Salvador: Centro Editorial de Didático da UFBa, 1992.

STINER, Max. O único e a sua propriedade. Tradução de João Barrento. São Paulo: Martins, 2009. 